\title{
ND ISOTOPE SYSTEMATICS RELATED TO PROTEROZOIC EVOLUTION OF THE CENTRAL RIBEIRA BELT IN THE STATE OF SÃO PAULO, SE BRAZIL
}

\section{ELTON LUIZ DANTAS ${ }^{1}$, PETER CHRISTIAN HACKSPACHER ${ }^{2}$, ALLEN HUTCHESON FETTER $^{2}$, KEI SATO ${ }^{3}$, MÁRCIO MARTINS PIMENTEL ${ }^{1}$ AND ANTÔNIO MISSON GODOY ${ }^{2}$}

\begin{abstract}
New Sm/Nd data from different lithologic units of the Ribeira Belt (RB), southeastern Brazil, provide important information about the crustal architecture and geologic evolution of the region. Nd data of basement gneisses of the RB indicate that they represent Paleoproterozoic crustal growth, whereas those of the supracrustal sequences suggest provenance from both Paleoproterozoic and younger sources. On the basis of their Nd signatures, felsic brasiliano plutons derived largely from Paleoproterozoic basement, but systematic variations in their $\mathrm{T}_{\mathrm{DM}}$ model ages as a function of their chemistry may reflect differences in fractionation, vertical lithospheric heterogeneity, or possibly some contributions from the asthenospheric mantle.
\end{abstract}

Keywords: Nd signature, Ribeira Belt and Isotopic Evolution

INTRODUCTION The aim of this paper is to characterize the crustal architecture of the Ribeira Belt (RB), in the State of São Paulo, southeastern Brazil, through $\mathrm{Sm} / \mathrm{Nd}$ data of basement gneisses, granitoid suites and volcano-sedimentary sequences. These results, in turn, can be used to better understand the tectonic evolution and paleogeographic setting of the RB prior to the Brasiliano orogenesis.

The $\mathrm{Sm} / \mathrm{Nd}$ isotopic system has been widely used to investigate the crustal growth histories of different continental areas, e.g., Nelson \& DePaolo (1982), and can also be used to estimate of the nature and age of sediment sources, and thus useful for paleogeographic reconstructions (Barovich et al. 1989, Pimentel et al. 1999). $\mathrm{Nd}$ depleted mantle model ages ( $\left.\mathrm{T}_{\mathrm{DM}}\right)$ (also called "crust formation ages") are normally assessed using the deplete-mantle model of DePaolo (1981), calculating the isotopic evolution of a crustal sample from present its measured value, back through time when it had the isotopic composition of the depleted mantle reservoir. The slope of the evolution line is proportional to the measured $\mathrm{Sm} / \mathrm{Nd}$ ratio of the sample. However, $\mathrm{T}_{\mathrm{DM}}$ values do not necessarily represent the real age of a geological event and the interpretation of model ages of crustal rocks can be complex. As new crust forms, it acquires a Nd signature of the material involved in its genesis (Farmer \& DePaolo 1983, Arndt \& Goldstein 1987). Hence, if crust does not develop in isolation, i.e., an island arc setting, it can acquire an enriched or "reworked" $\mathrm{Nd}$ signature due to input from older crustal sources. In such a situation, the $\mathrm{T}_{\mathrm{DM}}$ age represents a hybrid crustal formation age (average crustal residence age), and the true age of the crust must be determined by other means, such as by $\mathrm{U} / \mathrm{Pb}$ zircon methods. Although the $\mathrm{Sm} / \mathrm{Nd}$ pair is relatively insensitive to fractionation in the continental crust during subsequent melting and metamorphic events, subtle fractionation can occur, creating changes in $\mathrm{T}_{\mathrm{DM}}$ ages. Also, as different magma types can be derived from various levels of the lithosphere, systematic variation in $\mathrm{T}_{\mathrm{DM}}$ ages may reflect vertical lithosphere heterogeneity, but also may be a result of contributions from asthenospheric mantle. In any case, variations in the model ages and other geochemical signatures must have geological significance (Sun et al. 1995, Zhao \& McCulloch 1995)

Several $\mathrm{Sm} / \mathrm{Nd}$ analyses have been done in the RB indicating a complex evolution history (Tassinari \& Sato 1996, Sato 1999, Ratgatki 1999). Cordani \& Sato (1999) used this methodology to understand the crustal evolution of the South American Platform.

GEOLOGIC SETTING The present configuration of tectonic blocks in the RB is due to lateral escape tectonics that occurred during the Brasiliano/Pan-African collision between the São Francisco and Congo cratons (Campos Neto \& Figueiredo 1995, Hackspacher et al. 1997). Regional data support the existence of a Paleo- and Mesoproterozoic blocks and terranes that were fused together during the Neoproterozoic.

The geological framework of the studied area consists of three lithotectonic domains (Figure 1): the São Roque, Jundiaí and Embu. The São Roque domain, characterized by low-grade (greenschist facies) metasedimentary and metavolcanic rocks, is bounded by the higher-grade (amphibolite facies) Jundiaí and Embu volcano-

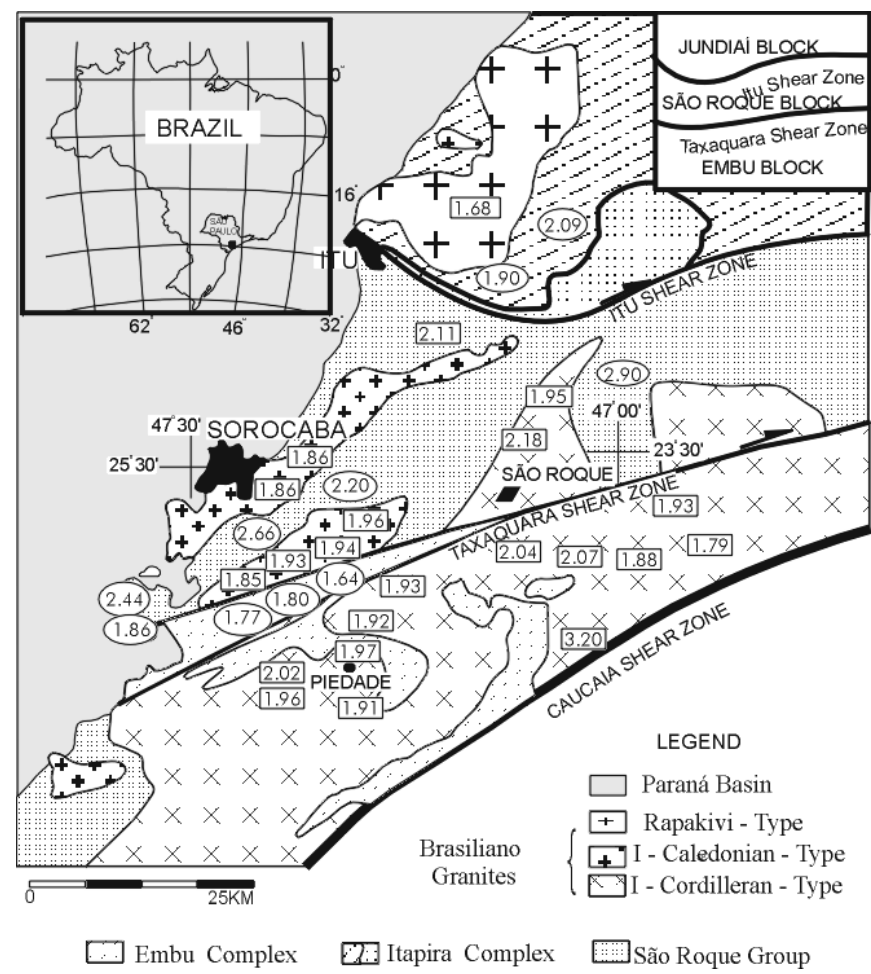

Figure 1-Distribution of TDM Nd model ages obtained for rocks of the Ribeira Belt in the São Paulo State. In the upper corner, we show the three different tectonic domains recognized in the study area.

sedimentary sequences. The contacts between these domains are NESE trending transcurrent shear zones. Paleogeographic reconstruction of the Neoproterozoic history of the RB (Hackspacher et al. 2000), suggest the development of a syn-collisional process involved the Embu and Itapira complexes, related to NW thrusting. The São Roque Group is considered as representing a continental back-arc environment that was generated during active collision. Lateral tectonic escape, combined with a vertical tectonic component, was responsible for juxtaposing deep and shallow levels of the crust presently exposed in the RB.

The Brasiliano magmatism is well represented in the three domains. These granitoids display a complex intrusive history that includes a distinctive young magmatic phase of circular small bodies intruding into older phases. These young plutons serve as a regional time marker. The evolutionary history of the plutonism, dated through $\mathrm{U} / \mathrm{Pb}$ geochronology, record episodes of early magmatism (possibly subduction-related), continental collision, transpression, uplift and collapse (Töfner 1996)

In the central RB the granitoids bodies can be subdivided into in

1 - Instituto de Geociências, Universidade de Brasília, 70910-900 Brasília - DF, Brazil elton@unb.br

2 - Instituto de Geociências e Ciências Exatas, Universidade Estadual Paulista, 13506-900, Rio Claro - SP, Brazil

3 - Instituto de Geociências, Universidade de São Paulo, 05422-970 São Paulo-SP, Brazil 
three major groups (Wernick et al. 1993): 1) - I-type Cordilleran calcalkaline granites cut by circular, dominantly, alkali-calcic bodies (São Roque, Ibiúna and Piedade granites), related to the syn-collisional phase of the Brasiliano Orogeny (ca. 629-625 Ma); 2) - I-type Caledonian alkali-calcic granites cut by circular rapakivi bodies (Sorocaba and São Francisco granites), and 3) - Circular Rapakivi granite plutons, forming isolated or coalescent intrusions (Itu granite) representing the post-collisional phase, dated at $580 \mathrm{Ma}$ (Töfner 1996).

SAMPLES AND ANALYTICAL PROCEDURES The samples were collected from all three of the domains described above. Several whole-rock samples of the São Roque, Sorocaba, São Francisco and Piedade granitoids, as well as host rocks of Embu and Itapira complexes, were analyzed by $\mathrm{Sm} / \mathrm{Nd}$ methods. Results are given in Table 1. In the past, the $600 \mathrm{Ma}$ used as a reference age to calculate the initial Nd isotopic composition $\left(\varepsilon_{\mathrm{Nd}}(\mathrm{t})\right)$ is due to the fact that this is the average age of the main magmatic event in the RB, and way be used to monitor the effect of late fractionation in these rocks.

The data represents the first results obtained in the Isotope Geology Laboratory of the DPM/IGCE/UNESP. The isotopic analyses were accomplished in the IG/USP and in the IG/UnB, and the analytical procedures used are described in Sato et al. (1995) and Pimentel et al. (1996)

RESULTS The results of representative samples for each geologic domain of the Ribeira Belt are show in Table 1. All samples analyzed in this work are not in this table. The $\mathrm{T}_{\mathrm{DM}}$ model age distribution defines groups of values as presented below (Figure 2).
Jundiaí Dom ain

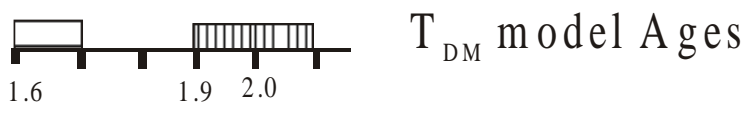

São Roque Domain

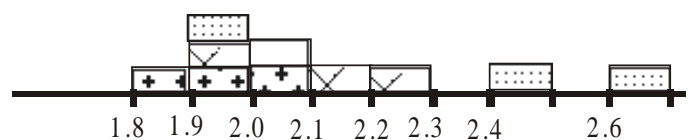

Embu Domain

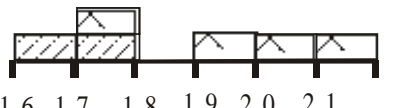

$\begin{array}{llllll}1.6 & 1.7 & 1.8 & 1.9 & 2.0 & 2.1\end{array}$

Granites

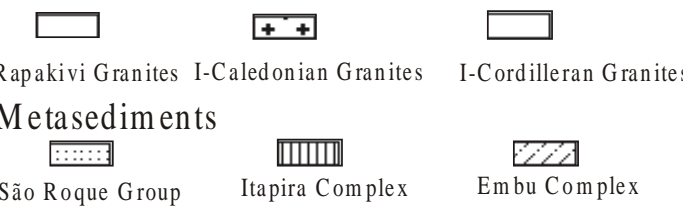

Figure 2 - Histogram of TDM Nd values from metasedimentary rocks and granitoids of different domains identified in the Ribeira Belt. Each box corresponds to one Sm-Nd analysis to granitoid rocks and ellipse to the supracrustal rock.

Table 1 - Representative Sm-Nd results of metasediments of São Roque, Embu and Itapira complexes and intrusive granitoid rocks that occur in the different domains of the Ribeira Belt.

\begin{tabular}{|c|c|c|c|c|c|c|c|c|}
\hline Sample & Rock Type & $\begin{array}{c}\text { Sm } \\
(\mathbf{p p m})\end{array}$ & $\begin{array}{c}\text { Nd } \\
(\mathbf{p p m})\end{array}$ & ${ }^{147} \mathrm{Sm} /{ }^{144} \mathrm{Nd}$ & ${ }^{143} \mathrm{Nd} /{ }^{144} \mathrm{Nd}$ & $\begin{array}{c}\varepsilon_{\mathrm{Nd}} \\
(\mathbf{0})\end{array}$ & $\begin{array}{c}\mathbf{T}_{\mathrm{DM}} \\
(\mathrm{Ma})\end{array}$ & $\begin{array}{c}\varepsilon_{\mathrm{Nd}} \\
(\mathrm{t}=0.6 \\
\mathrm{Ga})\end{array}$ \\
\hline \multicolumn{9}{|c|}{ SÃO ROQUE DOMAIN } \\
\hline H519 & Metarhythmite & 7.96 & 52.63 & 0.091423 & 0.511552 & -21 & 1.86 & -13 \\
\hline H511A & Metapelite & 6.54 & 35.85 & 0.110300 & 0.511500 & -22.2 & 2.28 & -15 \\
\hline H511B & Metapelite & 2.54 & 12.6 & 0.12200 & 0.511567 & -20.8 & 2.44 & -15 \\
\hline $\mathrm{H} 511 \mathrm{C}$ & Metapelite & 3.24 & 15.0 & 0.13030 & 0.511480 & -22.6 & 2.86 & -17 \\
\hline M9801E & Metabasite & 6.64 & 33.65 & 0.11930 & 0.511469 & -22 & 2.66 & -17 \\
\hline \multicolumn{9}{|c|}{ Granitoids } \\
\hline \multicolumn{9}{|c|}{ São Francisco Granite } \\
\hline H524 & Diorite & 15.15 & 92.7 & 0.09900 & 0.511567 & -20.8 & 1.94 & -13 \\
\hline H510 & Rapakivi granite & 14.4 & 92.1 & 0.09400 & 0.511495 & -22 & 1.96 & -14 \\
\hline H509 & Rapakivi granite & 10.81 & 73.3 & 0.08900 & 0.511524 & -21 & 1.85 & -13 \\
\hline H508 & Coarse granite & 9.92 & 51.27 & 0.11700 & 0.511637 & -19 & 2.20 & -13 \\
\hline H507 & Granite & 34.67 & 208.1 & 0.1000 & 0.511633 & -19 & 1.89 & -12 \\
\hline H518 & Diorite & 11.83 & 64.05 & 0.111700 & 0.511696 & -18 & 2.02 & -11 \\
\hline H514 & Leucogranite & 36.10 & 239.7 & 0.091047 & 0.511507 & -22 & 1.91 & -13 \\
\hline \multicolumn{9}{|c|}{ São Roque Granite } \\
\hline $\mathrm{H} 353$ & Granodiorite & 6.45 & 41.64 & 0.09369 & 0.511525 & -21.7 & 1.93 & -15 \\
\hline H357 & Monzogranodiorite & 3.55 & 20.06 & 0.1069 & 0.511514 & -21.9 & 2.18 & -15 \\
\hline \multicolumn{9}{|c|}{ JUNDIAÍ DOMAIN } \\
\hline H348 & Sillimanite gneiss & 1.90 & 7.31 & 0.12407 & 0.511864 & -16.2 & 2.09 & -09 \\
\hline H349 & Garnet gneiss & 2.27 & 12.29 & 0.11190 & 0.511789 & -17.1 & 1.90 & -10 \\
\hline \multicolumn{9}{|c|}{ Granitoids (Itu Granite) } \\
\hline M347 & Rapakivi Granite & 8.00 & 52.98 & 0.09135 & 0.511691 & -18.5 & 1.68 & -10 \\
\hline \multicolumn{9}{|c|}{ EMBU DOMAIN } \\
\hline H513A & Paragneiss & 7.04 & 51.27 & 0.0830 & 0.511544 & -21.3 & 1.75 & -12 \\
\hline H513b & Paragneiss & 5.87 & 34.56 & 0.1026 & 0.511756 & -17.2 & 1.75 & -10 \\
\hline H528 & Migmatite & 10.79 & 65.46 & 0.099 & 0.511687 & -18 & 1.80 & -11 \\
\hline H529 & Migmatite & 2.66 & 18.3 & 0.088 & 0.511682 & -18 & 1.64 & -10 \\
\hline \multicolumn{9}{|c|}{ Granitoids (Piedade Granite) } \\
\hline VOX36 & Piedade Granite & 8.32 & 55.31 & 0.091014 & 0.511469 & -23 & 1.96 & -14 \\
\hline V0X25 & Granodiorite & 4.78 & 37.09 & 0.077859 & 0.511329 & -26 & 1.93 & -16 \\
\hline
\end{tabular}


Paragneisses/supracrustal rocks THE SÃO ROQUE DOMAIN $(S R D)$ Data for low-grade metasedimentary and metavolcanic rocks of the São Roque Group indicate provenance from Paleoproterozoic sources with a hint of younger source material input. Metarhythmites have $\mathrm{T}_{\mathrm{DM}}$ ages of $2.44 \mathrm{Ga}$ while the phyllites yield $\mathrm{T}_{\mathrm{DM}}$ ages of 1.86 Ga with $\varepsilon_{\mathrm{Nd}}(600)$ values of ca. -15 . Neoproterozoic metamafic rocks (metadiorites and amphibolites) intercalated in these metasediments possess $\mathrm{T}_{\mathrm{DM}}$ ages of 2.66 and $2.20 \mathrm{Ga}$. These values suggest that the igneous rocks were derived from Paleoproterozoic, and possibly Archean lithosphere.

THE JUNDIAí DOMAIN (JD): The garnet-bearing migmatites and sillimanite and garnet-bearing granitic gneisses of the Itapira Complex, the main unit of this domain, yield $\mathrm{T}_{\mathrm{DM}}$ ages between 1.93 and $2.09 \mathrm{Ga}$ with $\varepsilon_{\mathrm{Nd}}(600)$ values of ca. -10 .

THE EMBU DOMAIN (ED): Paragneisses and migmatitic paragneisses of the Embu Complex, the main geological unit of the domain, yield $\mathrm{T}_{\mathrm{DM}}$ values between 1.64 and $1.80 \mathrm{Ga}$ and $\varepsilon_{\mathrm{Nd}}(600)$ values around -12 . The younger $\mathrm{T}_{\mathrm{DM}}$ ages of this domain suggest the sedimentary protolith of these gneisses derived from younger (Neoproterozoic?), as well as Paleoproterozoic sediments.

Granitoids The Embu Domain is intruded by the syn-collisional Piedade and Ibiuna granites. The first is composed mainly of megaporphyroid biotite monzogranites, with $\mathrm{T}_{\mathrm{DM}}$ values varying between 1.97 and $1.96 \mathrm{Ga}$. Dioritic enclaves and late leucogranites yield $\mathrm{T}_{\mathrm{DM}}$ ages of $2.02 \mathrm{Ga}$ and $1.91 \mathrm{Ga}$, respectively. The Ibiuna massif presents spatial variation in the $\mathrm{T}_{\mathrm{DM}}$ ages, with values decreasing from the center to the border of the batholith. The central porphyroid monzogranites shows values between 2.14 and 1.93, and the subordinate quartz diorite and granodiorite, presents values between 1.82 and $1.79 \mathrm{Ga}$.

The late collisional São Roque, Sorocaba and São Francisco granites are intrusive along strike-slip shear zones, in the SRD. The São Roque granite is a high-K calc-alkaline pluton whose predominant facies is made of mega-porphyritic monzogranites with $\mathrm{T}_{\mathrm{TM}}$ of 2.18 $\mathrm{Ga}$, while late equigranular facies show values of $\mathrm{T}_{\mathrm{DM}}$ of $1.95 \mathrm{Ga}$. The Sorocaba granite (Godoy 1989) is represented by coarse-grained monzo and sienogranites, with $\mathrm{T}_{\mathrm{Dy}}$ values varying between $2.11 \mathrm{Ga}$ for the porphyroid facies and $1.86 \mathrm{Ga}$ for the equigranular facies. The São Francisco granite (Godoy 1989) consists of a dominantly porphyritic monzogranite with a $\mathrm{T}_{\mathrm{DM}}$ age of $1.93 \mathrm{Ga}$. The subordinate equigranular syenogranites, coarse-grained syenogranites and equigranular monzodiorites show $\mathrm{T}_{\mathrm{DM}}$ values of $2.20 \mathrm{Ga}, 1.94 \mathrm{Ga}$ and $1.89 \mathrm{Ga}$, respectively. Even-grained and porphyritic rapakivi facies of circular plutons that cut the batholith show $\mathrm{T}_{\mathrm{DM}}$ age varying from 1.85 to $1.96 \mathrm{Ga}$ and $\varepsilon_{\mathrm{Nd}}(600)$ values ranging between -15 and -11 .

The Itu granite is intrusive into the JD during the post-collisional phase, and yields $\mathrm{T}\left({ }_{\mathrm{DM}}\right)$ values of $1.68 \mathrm{Ga}$ and $\varepsilon_{\mathrm{Nd}}(600)$ values of -10 .

DISCUSSION The Sm-Nd data of granitoids and paragneisses of the RB (São Roque Group, Embu and Itapira complexes) show that this method is useful for chronological determination of events related to different periods of continental crust formation and to constrain the genesis and space and time relationships of the pre-Brasiliano history of the RB. The data presented above suggest that:

i) The basement rocks to the supracrustal sequences and granitoids are dominated by Paleoproterozoic units, as evidenced by the majority of $\mathrm{T}_{\mathrm{DM}}$ ages between 1.9 and $2.4 \mathrm{Ga}$. Although the minor difference in the Nd signatures of the Embu, Jundiaí and São Roque domains, the variation does not indicate an amalgamation of separate exotic terranes. Rather, it appears that these tectonic domains are part of the same crustal or lithospheric block that was

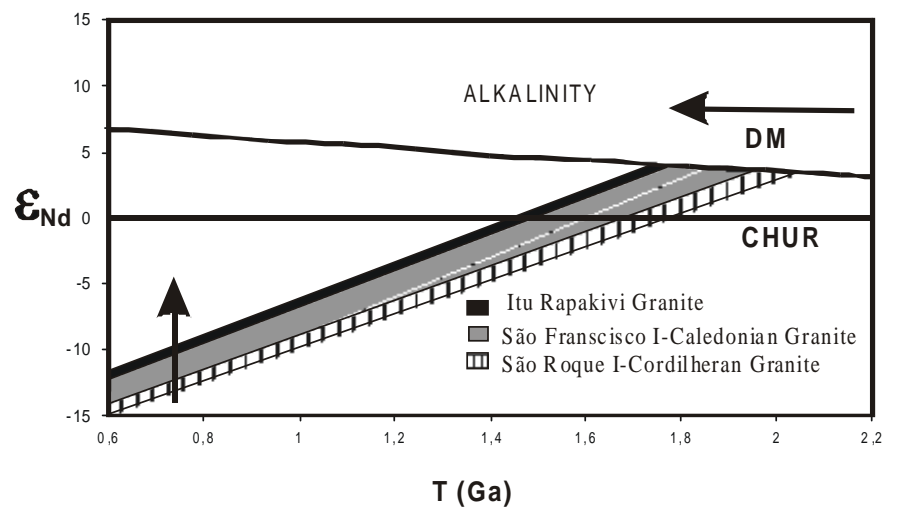

Figure 3 - Nd isotopic composition diagram to granitoids of the São Roque, São Francisco and Itu Granites. The arrow indicates the variation of $\mathrm{T}_{\mathrm{DM}}$ and eNd values with increasing of alkalinity from I-Cordilleran, I-Caledonian to Rapakivi types.

dismembered during the transcurrent phase of the Brasiliano orogeny (Hackspacher et al. 1997). A single $\mathrm{T}_{\mathrm{DM}}$ age of $2.66 \mathrm{Ga}$ suggests the presence of an Archean crust in the region, but additional $\mathrm{U}-\mathrm{Pb}$ zircon studies of the basement are needed to confirm this. Figure 2 shows the rock types versus $T_{D M}$ model ages.

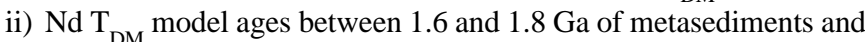
paragneisses of the Embu Complex suggest a mixture of Paleoproterozoic and younger detritus in the constitution of these rocks. The presence of some ca. 720 to $750 \mathrm{Ma}$ inherited zircons in volcanic rocks of the Sao Roque Group indicates that some Neoproterozoic crust may be locally present (Hackspacher et al. 2000). Studies of detrital zircons from the Embu and Itapira complex paragneisses should help constrain the ages of the source regions.

iii)Calc-alkaline and alkaline plutonism was synchronous in all three of the lithotectonic domains mentioned above (Wernick et al. 1993). A striking feature of several of these plutons, specifically the São Roque, Sorocaba and São Francisco granites, is that they display large variations in terms of $\mathrm{T}_{\mathrm{PM}}$ which values varying between $2.2-2.1 ; 2.0-1.95 \mathrm{Ga}$ and $1.89-1.86 \mathrm{Ga}$, respectively (Figure 3 ). This suggests that these intrusions grew by accretion through a series of magmatic pulses into the batholiths. The observed heterogeneity is interpreted to reflect changes in the magma sources over time. These changes may reflect differential crustal contamination, as proposed by Dantas et al. (1999). These variations, however, also may reflect a heterogeneous lithosphere or increasing contributions from the asthenosphere (as suggested below). The youngest $\mathrm{T}_{\mathrm{DM}}$ model age of the Itu granite $(1.68 \mathrm{Ga})$ may reflect a derivation from both Paleoproterozoic and younger lithosphere/crust. Alternatively, the decrease of eNd and $\mathrm{T}_{\text {DM }}$ values with increase of alkalinity, also may be the result of melts derived from Paleoproterozoic lithosphere and Neoproterozoic asthenosphere. While the evolved nature of this kind of magmatism may seem at odds with the latter interpretation, the presence of evolved felsic rocks derived from asthenospheric mantle is well documented in the western United States, e.g. Perry and DePaolo (1988) and Perry et al. (1993).

Acknowledgements To FAPESP (projects 97/06544-8 and 97/ 1397-9) and CNPq (project 52.2386/95-7) for financial supports, and to Dr. Eberhard Wernick for suggestions and discussions, and to two anonymous referees of RBG for critical review of the manuscript.

\section{References}

Ardnt N.T. \& Goldstein S.L. 1987. Use and abuse of crust-formation ages. Geology, 15:893895

Barovich K.M., Pattchet P.J., Peterman Z.. Sims P. K. 1989. Nd isotopes and the origin of 1.9-1.7 Ga Penokean continental crust of the Lake Superior region. Geol. Society of America Bulletin, 101:333-338

Campos Neto M. C. \& Figueiredo M. H. 1995. The Rio Doce Orogeny, southeastern Brazil J. South. Amer. Earth. Scie. 8:143-162.
Cordani U. \& Sato K. 1999. Crustal evoltution of the South American Plattaform, based on $\mathrm{Nd}$ isotopic systematics on granitoid rocks. Episodes, 22:167-173.

Dantas E., Hackspacher P., Godoy A.M., Sato K., Pimentel M., Oliveira M.A.F., Fetter A. 1999. Characterization of the generating sources of continental crust of the Ribeira belt through isotope of Nd in the State of São Paulo, SE of Brazil. In: South American Symposium on Isotope Geology 2, Villa Carlos Paz, 1999. Actas Córdoba, IGRM. p. 192-195. 
DePaolo D. 1981. Neodymiun isotopes in the Colorado Front Range and crust-mantle evolution in the Proterozoic. Nature, 291:193-196.

Farmer G .L \& De Paolo D. 1984. Origin of Mesozoic and Tertiary granites in the western U. S. and implications for pre-Mesozoic structure. 2. $\mathrm{Nd}$ and $\mathrm{Sr}$ isotopic studies of unmineralized and $\mathrm{Cu}$ - and Mo-mineralized granites in the Precambrian craton. $J$. Geophys. Res., 89:10,141-10,160.

Godoy A.C.M. 1989. Caracterização faciológica e Petrográfica e geoquímica dos Maciços granitóides Sorocaba e São Francisco. Unplublished $\mathrm{PhD}$ thesis, 220p. IG/USP

Hackspacher P.C., Dantas E.L, Van Schmus W.R., Fetter A. 1997 . Terrenos exóticos na Faixa Ribeira? sim ou não. VI SNET. Pirenópolis, Goiás 72-74.

Hackspacher P., Dantas E.L., Spoladore A, Fetter A \& Oliveira M.A.F. 2000. Evidence for Neoproterozoic back-arck basin development in the Central Ribeira Belt, Southeastern Brazil: New geochronological and geochemical constraints from the São Roque - Açungui Groups. Rev. Bras. Geoc. (in this volume)

Hackspacher P.C. \& Godoy A.M. 1999. Vertical displacement during late-collisional escape tectonics (Brasiliano Orogeny) in the Ribeira Belt, São Paulo State, Brazil. Journal of African Earth Sciences, 29:25-32.

Nelson B.K \& DePaolo D. 1985. Rapid production of continental crust 1.7 to 1.9 b.y ago: $\mathrm{Nd}$ isotopic evidence from the basement of the North American mid-continent. Geol. Soc. Am. Bulletin, 96:746-754.

Perry F.V., DePaolo D.J., Baldrige W.S. 1988. Chemical and isotopic evidence for lithospheric thinning beneath the Rio Grande rift. Nature, 332:432-434

Perry F.V., DePaolo D.J., Baldridge W.S. 1993, Neodymium isotopic evidence for decreasing crustal contributions to Cenozoic ignimbrites of the western Unites States:
Implications for the thermal Cordilleran crust. Geol. Soc. Am. Bulletin, 105:872-882.

Pimentel M.M, Dardenne A.M., Viana M.G., Gioia S.M.L.C., Jungles S., Seer H.J. 1999 $\mathrm{Nd}$ isotopes and the provenance of sediments of the Neoproterozoic Brasília Belt, central Brazil: geodynamic implications. In: South American Symposium on Isotope Geology 2, Villa Carlos Paz, 1999. Actas, Córdoba, IGRM, p. 426-429.
Pimentel M, Fuck R., Del'Rey Silva L.J. H. 1996. Dados Sm-Nd da região de JussaraGoiás- Mossâdes (GO), e o limite do entre terrenos antigos e do Arco Magmático de Goias. Rev. Bras. Geoc., 26:61-70.

Ragatky D. 1988. Contribuição à geoquimica e geocronologia do domínio São Roque e do Nappe de Socorro-Guaxupé na região de Igaratá e Piracaia, SP. Doctoral Thesis. Instituto de Geociências/USP, 130p.

Sato K., Tassinari C.C.G, Kawashita K, Petronilho L. 1995 . O método Sm/Nd no IG/USP e suas aplicações Anais da Academia Brasileira de Ciências, 67:313-336.

Sun S., Warren R. G. and Shaw R. D. 1995. Nd isotope study of granites from the Arunta Inlier, central Australia: constraints on geological models and limitation of the Inlier, central Australia: constraints on geo
method. Precambrian Research, 71:301-314.

Tassinari C. \& Sato K. 1996. Idades de formação de crosta continental na parte sudeste do estado de São Paulo, com base em dados Sm-Nd. XXXIX Cong. Brasileiro de Geologia. Salvador, 6:489-492

Töpfner C. 1996. Brasiliano-Granitoide in den Bundesstaaten São Paulo und Minas Geraiseine vergleichende Studie. Münchner Geologische Hefte A17:258 p.

Wernick E., Hormann P.K., Artur A.C., Ferreira C.J., Galembeck T.M.B., Godoy A. M., Andrade F.R. 1993. Fases, impulsos e ciclos magmáticos em complexos granbitóides associados com falhas transcorrentes. Rev. Bras. Geoc., 23:248-259.

Zhao J. \& McCulloch M. T. 1995. Geochemical and Nd isotopic systematics of granites from the Arunta Inlier, central Australia: implications for Proterozoic crustal evolution. Precambrian Research, 71:265-299.

Contribution IGC-158

Received March 3, 2000 Accepted for publication April 26, 2000 